\title{
Common Factors of Cost Escalation in Construction Industry of Pakistan
}

\author{
Salman Ahmed \\ Department of Civil Engineering, \\ Quaid-e-Awam University of \\ Engineering, Sciences \& Technology, \\ Nawabshah, Pakistan \\ engr.salamahmed@gmail.com
}

\author{
Abdul Nasir Laghari \\ Department of Chemical Engineering, \\ Quaid-e-Awam University of \\ Engineering, Sciences \& Technology, \\ Nawabshah, Pakistan \\ laghari@hotmail.com
}

\author{
Aftab Hameed Memon \\ Department of Civil Engineering, \\ Quaid-e-Awam University of \\ Engineering, Sciences \& Technology, \\ Nawabshah, Pakistan \\ aftabm78@gmail.com \\ Muhammad Akram Akhund \\ Department of Civil Engineering, \\ Mehran University of Engineering and \\ Technology, \\ Jamshoro, Pakistan \\ akhund42@gmail.com
}

\author{
Noor Ahmed Memon \\ Department of Civil Engineering, \\ Quaid-e-Awam University of \\ Engineering, Sciences \& Technology, \\ Nawabshah, Pakistan \\ nahmedmemon@gmail.com \\ Hafiz Usama Imad \\ Department of Civil Engineering, \\ Mehran University of Engineering and \\ Technology, \\ Jamshoro, Pakistan \\ usamaimad@yahoo.com
}

\begin{abstract}
Cost escalation is a ubiquitous problem, especially in Government organizations. Though bigger projects encompass escalation cost, in smaller projects, it is generally ignored. Several internal and external factors are responsible for the undesirably increased cost of a project. Among them some are tangible, and some are intangible. The scope of this study is to highlight most common remittable and non-remittable factors responsible for cost escalations. Thirty most common factors responsible were listed. A survey was done in order to have the stakeholder's opinion on identifying the most common factors. Out of 102 generally identified escalating factors, 30 factors were shortlisted based on literature and initial study. Participants responded on a 1 to 5 Likert's scale. Out of 200 distributed questionnaires, 52 reliable set of questionnaires were selected for data analysis. Clients, consultants, and constructors were selected from different projects like roads, structure, public amenities etc. Minimum threshold to participate in the survey was that a respondent must had at least a Diploma or Bachelor's degree in the field of civil engineering. Results highlighted that financial problems, slow payments, and inflation are the top-ranked identified factors responsible for cost escalation in the construction industry of Pakistan. The weighted average of all factors ranges between 0.355 and 0.688 , having $0.668,0.629$ and $\mathbf{0 . 6 2 5}$ for the top three factors.
\end{abstract}

Keywords-cost escalation; stakeholders; construction industry; Pakistan

\section{INTRODUCTION}

Cost escalation is referred as the change in the price of a given commodity or services for a given period of time in a given economy. In Pakistan, cost escalation is a ubiquitous problem, especially in Government organizations. Cost escalation is the adjustment or settlement of unit price of contract component which includes labor, construction materials and equipment to contract the value during bid and is almost inevitable in large construction projects [1]. Cost escalation often offsets the industry's contribution to the economy. Escalation and contingency expenses include unnecessary costs caused by the underestimation of the actual cost that exceeds the budget amount [2]. Cost escalation problem has various causes, therefore it is necessary to study the common factors responsible for cost escalation in construction industry of Pakistan.

Results of a research regarding Zambian road construction projects indicate that bad weather and flooding were major main reasons for cost increase. Another major reason was the payment delays from client to the contractors. Researchers suggest that there is no simple solution to control the cost increase and schedule delay. However, it can be controlled through good project management [3]. Cost escalation reasons occurring in projects of Nigeria's construction industry are unstable material prices and changes [4]. In Pakistani industry the main reason for rising costs is customer behavior [5]. Another survey of Pakistani construction works among key stakeholders indicated escalation of material prices and discontinuity of funds. Researchers suggested that there is immense need of proper planning at the earlier stage of estimation. Proper provision for contingencies should be kept to cover the escalation of material prices [6]. The Office of Government Accountability indicated that $77 \%$ of road projects in the United States failed in achieving completion within estimated cost. On the other hand, authors in [7] concluded that 9 out of every 10 construction projects experienced cost escalation. In Jordan, road projects were reported as overran due to terrain and weather conditions [8]. Analysis of cost issues in construction projects of India showed that changes in 
designs by the clients, fluctuations in material prices, delay in payments, changes in material types and specifications during construction, and reworks caused by errors during construction are considered seriously [9]. During the construction phase of Vietnam highway projects, land acquisition, capital and contract constraint, infrastructure construction investment management system, survey and design scheme, construction unit fiscal and management ability as threats for project cost were indicated in [10]. Poor planning, labor and material shortfall are considered as key reasons that affect project cost in India [11] while poor site management, lack of coordination, contractor's lack of experience and fraudulent practices were reported as major issues in Nigerian construction projects [12]. Road construction projects of Palestine showed fluctuation in prices, incomplete drawings, short time to prepare cost estimation, contract size and lack of experience as key factors affecting project cost [13]. Similarly, a survey investigation on road works of Saudi Arabia revealed administrative problems, delay payments, delay in decision making and poor communications between parties as most affecting factors [14]. Authors in [15] highlighted as major reason of cost escalation the inadequate project preparation. After a comprehensive review of the above mentioned studies, 30 top common factors were identified and considered for further investigation with respect to local construction industry. The factors are listed in Table I.

TABLE I. TOP COST ESCALATION FACTORS

\begin{tabular}{|c|c|c|}
\hline & Factors & References \\
\hline 1 & Fluctuation in material prices & {$[4,8-10,13,17-18]$} \\
\hline 2 & Weather conditions & {$[2-4,8,14]$} \\
\hline 3 & Frequent design changes & {$[8-10,12,14]$} \\
\hline 4 & $\begin{array}{l}\text { Cash flow and financial difficulties faced by } \\
\text { contractors }\end{array}$ & {$[4,10,11,17]$} \\
\hline 5 & Slow payments of completed works & {$[9-11,14]$} \\
\hline 6 & Lack of coordination on site & {$[2,4,12,14,17]$} \\
\hline 7 & Poor site and project management & {$[2,12,14,17]$} \\
\hline 8 & Inflation & {$[2,3,7,9,14]$} \\
\hline 9 & Poor contract management & {$[2,7,10,11]$} \\
\hline 10 & Labour productivity & {$[8,10,17]$} \\
\hline 11 & Local government pressures & {$[2,3,8,10]$} \\
\hline 12 & Poor technical performance & {$[2,8,10,11]$} \\
\hline 13 & Incorrect planning and scheduling & {$[12,16,18]$} \\
\hline 14 & Shortage of materials & {$[9,15,17]$} \\
\hline 15 & Low speed of decision making & {$[4,8,11,14]$} \\
\hline 16 & Government policies and political instability & {$[4,8,12,14]$} \\
\hline 17 & Increasing of loan interest rates & {$[10,12,14,16]$} \\
\hline 18 & Project location & {$[2,10,19]$} \\
\hline 19 & Insufficient/incomplete drawings & {$[4,13,19]$} \\
\hline 20 & Ground conditions & {$[8,12,19]$} \\
\hline 21 & Inaccurate estimate & {$[2,4,17,19]$} \\
\hline 22 & Unrealistic schedule & {$[4,12,19]$} \\
\hline 23 & Number of change/extra work orders & {$[2,6,9,17,19]$} \\
\hline 24 & Timeliness of subcontractors and suppliers & {$[2,7,9]$} \\
\hline 25 & Delay in land acquisition & {$[2,6,10,18]$} \\
\hline 26 & Inadequate contractor experience & {$[3,5,12,13]$} \\
\hline 27 & Strikes & {$[3,7,11,18]$} \\
\hline 28 & Absence of construction cost data & {$[4,8,12]$} \\
\hline 29 & Unavailability of competent staff & {$[6,17,18]$} \\
\hline 30 & Reworks due to the errors & {$[2,8,9,11]$} \\
\hline
\end{tabular}

\section{AIM OF STUDY}

The main aim of this research is to find the common factors of cost escalation in construction projects of Pakistan. The main objectives set under this scope were to explore cost escalation factors in construction projects throughout the world and to identify the common factors influencing cost escalation in construction projects of Pakistan.

\section{RESEARCH METHODOLOGY}

This study is based on a questionnaire survey, in which identified factors are presented to respondents from different contractor organizations working in Pakistan's construction industry. The respondents are requested to rate each specific factor on a five point Likert scale. To keep the reliability of the collected data, only respondents having minimum diploma or bachelor's degree in the field of civil engineering are selected. Statistical analysis of the collected data is done by Statistical software package (SPSS) Version 20 and Microsoft Excel. The questionnaire was designed according to the 30 factors of Table I from the total 102 cost escalation factors identified from the mentioned literature review and with the help of a pilot study. The questionnaire is divided into two parts, the first one focuses the respondent's demography, while the second one identified the probability of occurrence (POC) of factors causing cost escalation expressed in Likert scale from 1 to 5, with 1 meaning not occurrence and 5 meaning that the considered factor is very often occurring.

\section{DATA COLLECTION AND ANALYSIS}

In this quantitative and qualitative research the designed questionnaire was distributed among 200 construction practitioners involved in construction industry. Fifty two fully filled and valid questionnaires were received. Reliability test was conducted using Cronbach's Alpha, and its value was found to be 0.88 , which indicates well reliable data [20]. All successfully validated and reliable questionnaires from construction practitioners were analyzed by using weighted average (WA). Figure 1 illustrates the ratio of respondents involved in construction industry. The threshold value to rank the factor as common factor is 0.35 [3]. Figure 2, presents the ratio of data collection on the nature of project.

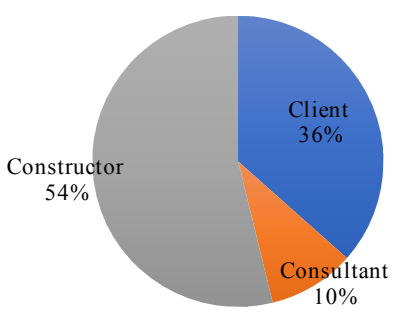

Fig. 1. Ratio of respondents from different organizations

The respondents were asked to rank the probability of occurrence level of each cost escalation factor in construction 
industry projects of Pakistan. The responses were analyzed with SPSS v 20 for determining frequency level. Weighted average (WA) was calculated with Microsoft Excel. The results regarding the probability of occurrence for all 30 factors are presented in Table II.

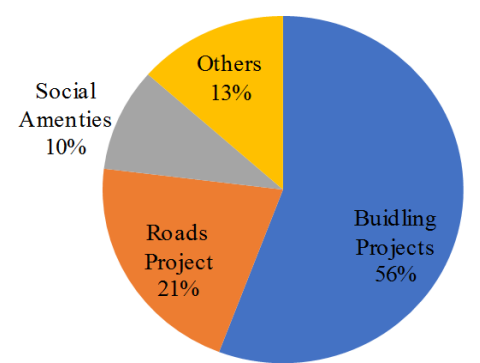

Fig. 2. Nature of construction projects

TABLE II. OVERALL FACTOR OCCURRENCE LEVEL AND RANKING

\begin{tabular}{|c|c|c|c|c|c|c|c|c|}
\hline \multirow{2}{*}{ Factor } & \multicolumn{6}{|c|}{ Frequency } & \multirow{2}{*}{ WA } & \multirow{2}{*}{ 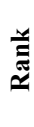 } \\
\hline & 1 & 2 & 3 & 4 & 5 & 吾 & & \\
\hline Cash flow and financial difficulties & 1 & 7 & 23 & 12 & 7 & 50 & 0.668 & 1 \\
\hline Slow payments & 5 & 9 & 15 & 14 & 6 & 49 & 0.629 & 2 \\
\hline Inflation & 1 & 17 & 15 & 5 & 10 & 48 & 0.625 & 3 \\
\hline Fluctuation in material prices & 1 & 16 & 15 & 14 & 5 & 51 & 0.624 & 4 \\
\hline Number of change/extra work orders & 5 & 22 & 12 & 8 & 5 & 52 & 0.546 & 5 \\
\hline Frequent design changes & 3 & 26 & 15 & 3 & 5 & 52 & 0.527 & 6 \\
\hline Shortage of materials & 3 & 29 & 7 & 9 & 1 & 49 & 0.502 & 7 \\
\hline Incorrect planning and scheduling & 8 & 23 & 11 & 7 & 3 & 52 & 0.500 & 8 \\
\hline Poor contract management & 7 & 25 & 10 & 9 & 1 & 52 & 0.492 & 9 \\
\hline $\begin{array}{c}\text { Government policies and political } \\
\text { instability }\end{array}$ & 7 & 27 & 10 & 4 & 4 & 52 & 0.488 & 10 \\
\hline Lack of decision making timely & 13 & 14 & 15 & 8 & 1 & 51 & 0.482 & 11 \\
\hline Weather conditions & 5 & 25 & 14 & 4 & 1 & 49 & 0.482 & 11 \\
\hline Poor site and project management & 7 & 28 & 9 & 3 & 4 & 51 & 0.478 & 12 \\
\hline Delay in land acquisition & 8 & 25 & 9 & 6 & 2 & 50 & 0.476 & 13 \\
\hline $\begin{array}{c}\text { Timeliness of sub-contractors and } \\
\text { suppliers }\end{array}$ & 13 & 17 & 15 & 3 & 3 & 51 & 0.467 & 14 \\
\hline Influence of local government & 10 & 24 & 9 & 2 & 4 & 49 & 0.461 & 15 \\
\hline Insufficient/incomplete drawings & 13 & 20 & 10 & 5 & 2 & 50 & 0.452 & 16 \\
\hline Inaccurate estimate & 9 & 27 & 10 & 4 & 1 & 51 & 0.447 & 17 \\
\hline Unrealistic schedule & 17 & 17 & 8 & 6 & 3 & 51 & 0.447 & 17 \\
\hline Lack of coordination on site & 8 & 32 & 8 & 1 & 3 & 52 & 0.442 & 18 \\
\hline Rework due to errors & 16 & 16 & 16 & 4 & 0 & 52 & 0.431 & 19 \\
\hline Inadequate contractor experience & 20 & 15 & 10 & 5 & 2 & 52 & 0.423 & 20 \\
\hline Unavailability of competent staff & 17 & 19 & 13 & 1 & 2 & 52 & 0.415 & 21 \\
\hline Strikes & 23 & 14 & 8 & 3 & 4 & 52 & 0.412 & 22 \\
\hline Ground conditions & 14 & 24 & 8 & 4 & 0 & 50 & 0.408 & 23 \\
\hline Labour productivity & 20 & 17 & 9 & 5 & 1 & 52 & 0.408 & 23 \\
\hline Poor technical skills & 19 & 18 & 7 & 5 & 1 & 50 & 0.404 & 24 \\
\hline Absence of contract cost data & 18 & 23 & 4 & 2 & 2 & 49 & 0.384 & 25 \\
\hline Project location & 19 & 21 & 8 & 1 & 1 & 50 & 0.376 & 26 \\
\hline Increasing of loan interest rates & 19 & 23 & 6 & 1 & 0 & 49 & 0.355 & 27 \\
\hline
\end{tabular}

$1=$ Not occurring, $2=$ Slightly, $3=$ Moderately, $4=$ Often, $5=$ =ery often

From Table II we can define the top factors of cost escalation in construction projects in Pakistan. Results indicate that cash flow and financial difficulties is the most commonly occurring factor in the construction projects of Pakistan. The factor slow payments is ranked second, inflation is third, fluctuation in material prices is ranked fourth, and the number of change/extra work orders is placed fifth. These results are in accordance with [16]. Finance ability is the key driving force for each project, so normally cash flow and financial difficulties are identified as the top cost escalation factor. It is necessary to have a smooth transition and money flow among clients, consultants and constructors which are the prime stakeholders of any construction project. Slow payment flow is an important cause of cost escalation in the construction projects of any country. Cost inflation of material, labor and equipment is one of the most uncertain and uncontrolled factors, causing delay and cost escalation in the project. It is highlighted as third most common factor of cost escalation by this study. This factor of cost escalation is common in developing countries.

\section{CONCLUSION}

Pakistan construction industry is vulnerable to several threats. Two of the most important are cost escalation and time overrun. Through a review of previous research works, carried out globally, in cost escalation area of study, a total of 30 factors were considered. These factors were used in a survey form to collect the perception of the respondents regarding factors of cost escalation in construction projects of Pakistan. Data analysis revealed that cash flow and financial difficulties, slow payments, inflation, fluctuation in material prices, and number of change/extra work orders were reported as the most common occurring cost escalation factors in a construction project.

\section{RECOMMENDATIONS}

For overcoming the issues mentioned above, all stakeholders have to play their role for removing barriers, specially clients, consultants and contractors, who are mostly directly or indirectly involved in causing escalations. Following are some recommendations that should be thought upon in mitigating and minimizing cost escalations and time overrun.

- Clients should ensure adequate funds, land possession, feasibility study, proper designing, accurate estimation, uninterrupted allocation of requisite budget and timely decisions before or during execution.

- Clients play the most important role in reducing the impact of financial problems.

- Non-availability of construction materials issue can be avoided by a pre-planned purchase strategy.

- The project needs to be completed on time and if delay is caused by slow work progress by the contractor, financial damages may be imposed.

\section{REFERENCES}

[1] Y. S. W. Broto, T. J. W. Adi, E. Suryani, J. W. Soetjipto, "Project Cost Escalation Prediction Models Based on System Dynamic Approach", Third International Conference on Civil Engineering Research, Surabaya, Indonesia, August 1-2, 2017

[2] M. Muya, C. Kaliba, B. Sichombo, W. Shakantu, "Cost Escalation, Schedule Overruns and Quality Shortfalls on Construction Projects: The 
Case of Zambia", International Journal of Construction Management, Vol. 13, No. 1, pp. 53-68, 2013

[3] C. Kaliba, M. Muya, K. Mumba, "Cost Escalation and Schedule Delays in Road Construction Projects in Zambia", International Journal of Project Management, Vol. 27, No. 5, pp. 522-531, 2009

[4] N. Z. Muhammad, A. Keyvanfar, M. Z. A. Majid, A. Shafaghat, A. M. Magana, S. Balubaid, "Assessment of Cost Escalation factors for Building and Civil Engineering Projects in Nigerian Construction Industry: a Multiple Regression Approach”, Jurnal Teknologi, Vol. 74, No. 4, pp. 85-91, 2015

[5] M. Abas, S. B. Khattak, R. Akhtar, I. Ahmad, M. Ullah, I. U. Haq, "Identification of Factors Affecting Cost Performance of Construction Projects", Technical Journal, University of Engineering and Technology (UET) Taxila Pakistan, Vol. 21, No. 1, pp. 72-78, 2016

[6] N. Ejaz, I. Ali, M. F. Tahir, "Assesment of Delays and Cost Overruns during Construction Projects in Pakistan", available at: http://dl.lib.mrt.ac.lk/handle/123/9431, 2013

[7] B. Flyvbjerg, M. K. S. Holm, S. L. Buhl, "What Causes Cost Overrun in Transport Infrastructure Projects?”, Transport Reviews, Vol. 24, No. 1, pp. 3-18, 2004

[8] N. Al-Hazim, Z. A. Salem, "Delay and Cost Overrun in Road Construction Projects in Jordan", International Journal of Engineering and Technology, Vol. 4, No. 2, pp. 288-293, 2015

[9] P. Jadhav, D. Desai, A. Gupta, "Analysis of Construction Cost Overrun Causes by Contractor's View", Imperial Journal of Interdisciplinary Research, Vol. 2, No. 8, pp. 908-910, 2016

[10] H. A. Vu, J. Wang, L. Min, S. H. Mai, "Research on Cost Overrun Risk of Construction Phase of Vietnam Highway International Contracting Project", Scientific Research Publishing, Vol. 8, pp. 86-98, 2016

[11] D. Bhatia, E. M. R. Apte, "Schedule Overrun and Cost Overrun in the Construction of Private Residential Construction Project: Case Study of Pune India", International Journal of Technical Research and Applications, Vol. 4, No. 2, pp. 174-177, 2016

[12] A. Haruna, S. U. Kunya, M. Mohammad, "Factors Affecting the Contractor's Cost Overrun of Building Project in Kano State, Nigeria", Journal of Multidisciplinary Engineering Science and Technology, Vol. 3, No. 1, pp. 3648-3652, 2016

[13] I. Mahamid, A. Bruland, "Cost Overrun Causes in Road Construction Projects: Consultants Perspective", 2nd International Conference on Construction and Project Management, Singapore, September 16-18, 2011

[14] A. Alhomidan, "Factors Affecting Cost Overrun in Road Construction Projects in Saudi Arabia", International Journal of Civil and Environmental Engineering, Vol. 13, No. 3, pp. 1-4, 2013

[15] A. Ebrahim, A. Y. Akal, "Modeling Schedule Overrun and Cost Escalation Percentages of Highway using Fuzzy Approach", Engineering, Construction and Architectural Management, Vol. 24, No. 5, pp. 809-827, 2017

[16] M. A. Akhund, T. H. Ali, N. A. Memon, S. H. Khahro, "Causal Attributes of Cost Overrun In Construction Projects of Pakistan", International Journal of Civil Engineering and Technology, Vol. 8, No. 6, pp. 477-483, 2017

[17] D. S. Tejale, S. D. Khandekar, J. R. Patil, "Analysis of construction project cost overrun by statistical method", International Journal of Advanced Research in Computer Science and Management Studies, Vol. 3, No. 5, pp. 349-355, 2015

[18] S. Durdyev, S. Ismail, N. A. Bakar, "Factors causing cost overruns in construction of residential projects: case study of Turkey", International Journal of Science and Management, Vol. 1, No. 1, pp. 3-12, 2012

[19] K. Knight, A. R. Fayek, "A preliminary study of the factors affecting the cost escalation of construction projects", Canadian journal of Civil Engineering, Vol. 27, No. 1, pp. 73-83, 2000

[20] M. A. Akhund, A. R. Khoso, A. A. Pathan, H. U. Imad, F. Siddiqui, "Risk Attributes, Influencing the Time and Cost Overrun in Joint Venture Construction Projects of Pakistan”, Engineering, Technology \& Applied Science Research, Vol. 8, No. 4, pp. 3260-3264, 2018 